\title{
Editorial: Emerging Perspectives on Post-Conflict Police-Community Relations II [1]
}

\author{
Ingrid L.P. Nyborg* and Daniel Juddson Lohmann \\ Norwegian University of Life Sciences (NMBU), Ås, Norway \\ * Corresponding author: E-Mail: ingrid.nyborg@nmbu.no; Tel.: +47 67231325, +47 95904751
}

Published: 5 May 2020

The world is increasingly interconnected - insecurity in one country can both directly and indirectly affect the security of people, countries and regions that are far away. Therefore, when conflict erupts in one part of the world, the international community responds in various ways to mitigate its effects, both locally and internationally. Whether it be through the provision of police, military and/or civilian personnel, humanitarian assistance, or post-conflict development assistance, the international community has repeatedly attempted to mitigate the effects of conflict, as well as to contribute to reforms which might lead to the prevention of local and global insecurity in the future.

To achieve these broad goals of prevention, the international community has invested heavily in security sector reform (SSR). While much of the focus of these efforts remains on peacekeeping and military support, there has been a growing interest in supporting longer-term police reform processes in post-conflict contexts as a way to strengthen rule of law and contribute to democratic institution-building. Despite decades of experience with international support to police reform, the evaluations of these missions have pointed to serious problems in the ways in which police reform assistance has been implemented. Several high-level reports and research papers have, for example, noted the increased militarization of the police and the lack of local ownership of police reform processes $[2,3]$. Specifically, the policing approaches chosen for post-conflict settings have not enabled the establishment of democratic, accountable policing institutions that effectively protect the population from violence and human rights abuses. Nor have they contributed to the building of trust between the police and the population to ensure that people feel safe and that their rights are ensured. What has gone wrong? Is a paradigm shift in policing necessary in these contexts?

This Special Issue is dedicated to exploring communityoriented policing (COP) and police reform in a series of post-conflict contexts: Kosovo, Guatemala, Afghanistan, Pakistan, Somalia and Kenya. The papers are based on mixed-methods research conducted under the EU-funded project 'Community-Oriented Policing and Post-Conflict Police Reform'(ICT4COP 2015-2020) [4]. In this project we explore how police reform in volatile contexts has taken place, and whether a focus on COP approaches rather than militarized approaches might be more effective in building trust, preventing violence and ensuring human security. We also explore some of the ways in which information and communications technology (ICT) might contribute to improving communication and trust between the police and communities in these challenging contexts [5]. In order to discover new insight into these issues, the research has been empirically informed, interdisciplinary and qualitative, as well as co-produced through the inclusion of police, civil society organizations and local women and men in the discussion of research results from its inception. This has provided an innovative take on understanding post-conflict policing, one which suggests the need to think anew some of our basic understandings and assumptions about conflict, security, policing, reform and technology. 


\section{Post-Conflict}

'Conflict' is a broad term that can range from low-level conflicts between individuals, to larger conflicts at sub-national or regional levels. In our research, the use of the term postconflict refers to the period following an intense, violent conflict, and where there has been a particularly focused response nationally and/or internationally to improve relations between the government and its citizens, or within society in general, through peace building, development and SSR. The cases included in the project and this special issue have all experienced such larger conflicts, but the nature of conflict has of course been qualitatively different in each historical context. For example, in Kosovo there was ethnic violence, a war, and a contentious independence movement (1990-2008), in Guatemala, there was ethnic conflict and a lengthy civil war (1960-1996), in Afghanistan there was first an occupation by the USSR, and then a civil war (1979-2001), in Pakistan there was an armed conflict in the Swat Valley (2009) and unrest in the border areas with Afghanistan, in Kenya there has been decades of ethnic violence and a slew of terror attacks, and in Somalia there has been unrest and civil war that has stretched on for nearly thirty years. Each of these situations has yielded unique research insights, demonstrating that a diversity of contexts must be met by a diversity of approaches within COP.

Within this diversity, however, there remains a common aim to gain stability and rebuild trust when armed conflict has ceased, both between the government and the population, and between different sectors of the population. However, it is important to note that despite the passing of a formal political peace process, violent conflict never completely ends [6]. Conflict persists at several levels pre-existing conflicts resurface, new conflicts emerge, and violence can be extreme. In one sense, conflict can be considered as a part of everyday life, and, therefore, something that cannot be ended completely, but its violent forms can be minimized. How conflict is understood will influence how states, donors, and local communities work to rebuild or transform their societies. With this in mind, it is particularly crucial to have a close awareness of the networks of power relations within which reform is implemented. In 'Striving for the Impossible' (Hansen, this issue) [7], for example, the distinctions of power relationships in post-conflict areas are categorized and tied to different strategies of reform, arguing that any approach that assumes that 'one size fits all' is unlikely to be effective. To explore the significance of contextual diversity of reform, we have in this research chosen a broad array of case studies representing different stages of conflict and reform, including those which are currently experiencing a resurgence of major conflict, such as Afghanistan.

\subsection{Human Security and the Security-Development Nexus}

Perhaps the most central concept framing our research is human security. Our choice of human security as a frame- work is critically anchored in wider debates on security and development in which issues of state building, peacebuilding, post-conflict violence, SSR and COP are tightly embedded. Intensified interest in the relationship between security and development, and the growing recognition of their close interlinkage, led to the emergence of new thinking around security and development in the post-9/11 era of terrorism and the rise of global threats [8]. A growing recognition of the failure of conventional security approaches to provide the necessary conditions for sustainable development in critical contexts followed. This has resulted in the emergence of new perspectives on the linkage between security and development. Security and development were, for example, increasingly conceptualized as mutually reinforcing and a central link in transitions from conflict to recovery [9]. Subsequently, development policies favored greater integration of security matters while the scope of security policies moved to integrate development issues as well [10]. In practice, this resulted in the piloting of new constellations of collaboration between the security and development sector, some of which have been highly criticized due to the uneven influence of national and international security interests over development principles in post-conflict contexts where the military is in the driver's seat of reconstruction policy [11]. This was particularly problematic due to the clear focus on military perspectives of security of the state and goals of stability in SSR.

Despite the more recent inclusion of civilian dimensions in international SSR policy [12-14], practice continues to reflect a focus primarily on state security. Such an approach, however, has at least two serious limitations. First, an uncritical focus on strengthening state security can result in perverse outcomes such as international support for repressive regimes and elites. Second, this perspective limits our understanding of how people experience insecurities which fall outside of this conceptualization, but are nevertheless experienced and perceived as very real threats to their lives and well-being. This could include, for example, threats to health, livelihoods and resources, which may be either directly or indirectly connected to a conflict, but in ways that may not be so apparent from a military perspective. This can result in a police force trained in military tactics and as a paramilitary force, rather than as a service to protect the broader rights and interests of the population [15]. For example, it is possible to observe this in the case of Afghanistan where police at one point were trained by the military to increase the 'boots on the ground' needed to face the threat of insurgents, at the expense of training in regular policing skills [16].

While the debates around the security-development nexus provided a critical view of two competing worldviews on local and global relations, they did not offer much in terms of an analytical perspective that could bridge these two worlds in a constructive and innovative way. This is where human security was seen to fill the gap. The term was originally coined in 1994 by the UN as freedom from want, and freedom from fear, and expanded in 2003 to in- 
clude freedom to live in dignity. While much of the early focus was on finding a definition and listing of what types of insecurities comprise human security [17], the emphasis has shifted to an understanding of human security in broader, processual terms. Gasper [18], for example, examines human security with respect to whose security, security of what, to what extent, and against what threats, and its purpose. In doing so, he identifies a range of definitions, which comprise different human security discourses depending on the purpose and needs of the actors. Some of these definitions are narrow, for example as a security or interventionist policy [19], while others are rather broad, encompassing all of human development [20,21]. Common to many, and important for our research, is a focus on people rather than the state as the object of insecurity, a move beyond physical violence as the only threat, the interconnectedness of threats, and an understanding of humans as more than individuals but part of a social, political context, and as both vulnerable and capable [22]. Human security in this sense is both broadened in terms of what constitutes a threat and narrowed to focus on contextual and normative priorities [17].

The implications of choosing a human security approach for our research are many. Analytically, a human security discourse provides us with an intellectual bridge between disciplines, sectors and stakeholders. In doing so, it has enabled researchers, policymakers, and practitioners within security, development, policing, technology, political science and anthropology to engage with each other and directly with local women and men to understand and address the complexities inherent in a variety of post conflict contexts. A focus on human security has, thus, had significant implications for our methodologies. We investigate, for example, the ways in which different people define their own experiences of threats to their well-being. To access this information we have employed a qualitative, narrative, anthropological and co-productive methodology in our field studies. We have a strong focus on exploring the contextuality of insecurity. This has required us to pay attention to historical, social and political understandings of conflict and reform processes in each case. We do not only consider vulnerabilities and issues of protection, but capabilities and issues of empowerment i.e. considering how people work to secure their lives in light of conflict and insecurities, individually, collectively and through local state and non-state institutions. We consider the interconnectedness of insecurities in a particular context, and how they interact in each case to result in a particular constellation of roles, responsibilities and outcomes that are relevant for understanding human security. This allows us, for example, to not only critically analyze how police perform their duties in these challenging contexts, but their role in relation to other state and non-state institutions, and to civil society, in addressing and preventing insecurities. Again, this often has different features in each of the cases, as they represent particular histories and institutional constellations.

An important dimension of our use of human security is our focus on the social foundations of power relations, and how they influence the ways in which police reform is both implemented and practiced. We consider, for example, how unequal power relations between the international community (military and police advisors) and local, relatively weak post-conflict governments influence the way in which community policing is designed and implemented both nationally and locally $[23,24]$. This power imbalance has sparked concern that the international community has introduced COP and that it represents not only an adherence to liberal peace strategies [25-27] by powerful nations in international politics, but also a Western philosophy and policing strategy that is irrelevant to different settings abroad. The role of the international community in COP implementation is discussed in detail in several articles in the first special issue $[16,28,29]$.

Likewise, power relations within and between national government actors, non-government actors, security actors, civil society and local communities are also examined, including issues of youth, gendered relations and the position of vulnerable groups. In this issue, Gjelsvik's article on the case of Kenya demonstrates how unique power structures between (and within) civil society, the police and the state have provided a challenging landscape for any success from its two state-led COP initiatives [30].

Coenders' article illustrates unique youth perspectives on rampant systematic corruption, nepotism, and incompetency in the Kosovo police, and reveals the security needs of a largely overlooked group [31]. Likewise, Ganapathy, Nimruzi, Ullah's article on Afghanistan and Pakistan compares how youth are both vulnerable and a resource, whose empowerment (or disempowerment) in society hold significant consequences for the future of both countries [32]. In all of our cases, we see that the inclusion of power relations at all levels enables a more critical and complex analysis of the possibilities and limitations faced in police reform that go beyond an instrumental understanding of challenges in terms of lack of resources and training.

\section{Community-Based Policing (COP)}

There is broad agreement that without community involvement and support, police reform efforts have little chance to prove successful [15,33-35]. COP is thus now widely recognized as a relevant approach to policing and restoring trust in police/community relations even in post-conflict contexts. Despite decades of research on COP, however, there remains a lack of consensus on both its definition and practice (See for example [24,36-43]). Thus, COP is understood and implemented differently in different contexts across the globe. Our research tries to fill some of the gaps in our understanding of what COP is, and how it might contribute to post-conflict police reform. There are three issues we feel are important to note at this point: focus on community, the challenges and opportunities of diversity of definition, and the challenges of international police assistance in reform. 


\subsection{COP and Community}

As mentioned in the previous section, a focus on human security in police reform shifts attention to addressing people's insecurities, and a focus on COP could offer a strategy to do so. While COP does have an inherent focus on community as a subject of security, there is a nevertheless a lack of attention in the COP literature to how the community should in fact be understood. Who is the community in COP? Research and analysis on COP has largely ignored people and their engagement in police reform and democratization processes. The diversity of people themselves, the changes that they have lived through both during and after decades of conflict, and their relation to governmental law enforcement agencies like the police has not been adequately addressed $[44,45]$. We therefore suggest that the thinking and practice of COP could benefit from more attention to 'community' through an in-depth qualitative understanding and integration of local experiences [24]. Our research offers insight from extensive interviews with local community members, including vulnerable groups such as women, youth and minorities, who reflect on both their own insecurities, and the possibilities of building trust between the police and communities. Noteworthy examples in this issue include the articles from Kosovo (Coenders, this issue) [31] and Afghanistan and Pakistan (Ganapathy, Nimruzi, Ullah, this issue) [32], which feature thorough perspectives from youth and women in each of these areas. Additionally, research from Kenya in this issue [30] represents a variety of voices from women's, youth, human rights, and religious organizations.

\subsection{Diversity of Definition}

The diversity of definitions of COP is also challenging for police reform. Studies focusing on post-conflict police reform see the role of COP differently. Some focus on the way COP might contribute to police effectiveness in terms of quality, responsiveness and accountability of police services. Others focus on engaging with communities for communitybased solutions to local issues re-establishing the broken links between communities and police, establishing them where they may never have existed, or re-negotiating them where they were poor in the past, improving public perceptions of the police, and rehabilitating the police institution in a way that encourages citizens to trust, interact and support their police in preventing, reporting and fighting crime and terrorism [46].

While such diversity can lead to experimentation and innovation towards improvements in human security, it can also result in lack of clarity and competing perspectives, which may hinder positive effects of reforms, both internationally and nationally. In Police Reform and Community Policing in Kenya (Gjelsvik, this issue) [30], the different approaches to COP implemented by different parts of the security sector, within the same country, implemented side-by-side, has earned COP the reputation as being "a chameleon", due to its "vagueness around initiatives" [47].

This has done little to enlist the trust of communities, particularly in light of Kenya's colonial policing history. This research reveals that COP initiatives failed to take account of this history, where the police were beset by corruption and were often a source of violence and even in some cases criminal activity. Community participation in COP was therefore low out of fear that individuals who collaborated with the police would have their names recorded and even be punished for participation. Each approach is as well aligned with different political interests, which again have different perspectives on what the role of the police in fact is in terms of its interaction with communities.

In our research we ask what we can learn from this diversity. We ask whether there are ways of understanding trust-building, accountability, government-civil society relationships that are contextually specific, but can nevertheless inform an understanding of COP on a broader level. Indeed, we hope this might provide some new insight that can be used to improve reform processes and contribute to improved human security for all. What we are learning from our cases, is that post-conflict reform processes have tended to focus on administrative and territorial questions, as well as the activities of international actors and the specific interests of donors, rather than on the specific interests and needs of citizens. While the steps required to promote COP in postcolonial Kenya may differ greatly from those of indigenous areas of Guatemala, we do witness general commonalities between these cases. This diversity of cases emphasizes the need to address human concerns to foster trust between communities and police, and the need for well-funded programs in which participants fully understand they are being heard.

\subsection{International Police Reform Assistance}

Whilst COP is now widely recognized as a strategic aspect of police assistance programs, how it relates to conventional approaches to police reform needs to be studied more closely. Institutional reforms of the police in post-conflict settings has often involved support to, for example, institutional re-structuring, establishment of and improvements in police training and education systems, human capacity building in both operations and strategy development, and upgrading of equipment. The focus has often been on improving police efficiency and effectiveness in maintaining the rule of law and can also involve links to reforms of the judiciary and prison sectors. In the aftermath of armed conflict, however, police-community relations and trust levels in society in general are typically very low. In our project we have tried to identify how police reform processes can contribute to greater cooperation between law enforcement agencies and citizens in post-conflict contexts. In some cases this dynamic is complicated by histories in which citizens may have recently been the victims of abuse by the same law enforcement agencies before, during and post-conflict.

The increased attention to COP in police reform in inter- 
national police missions, however, has proved challenging. International police advisors often experience frustration in their missions, and typically report a lack of adequate knowledge on COP and the specific contexts in which they conduct their assignments [48]. They often rely on their national understanding of COP, even when working on developing 'locally owned' forms of COP for the country where they are posted. They can as well face ethical dilemmas when local institutions seem at odds with international human rights. Likewise, national actors may feel that COP is a Western approach to policing that is imposed upon them. They may experience a lack of consideration of and respect for existing traditional conflict resolution and justice institutions and mechanisms when COP is being designed and implemented.

The tensions arising at the interface of international, government and traditional institutions is a recurring theme in several of our research cases. Rather than fall into an essentialist, binary discussion of what such relations and roles should be, our cases attempt to unravel the complexities and dilemmas inherent in these interfaces. The article on state institution building notes that supporters, donors and facilitators of security sector and police reform often expect a Western configuration of the state, where responsibility is clearly located in a uniform organizational hierarchy (Hansen, this issue) [7]. By distinguishing four drastically different configurations of (state) power organization, the importance of recognizing, understanding, and often working with non-state security providers within COP efforts is made readily apparent. These cases demonstrate that we need a more nuanced understanding of these relationships in order to move beyond a view of local institutions as always a problem, and international assistance as always an imposition.

There is also need for a discussion regarding the institutionalization and sustainability of COP in police reform assistance. When international actors depart and national actors take over, COP activities may continue as planned, be discontinued, or change into something quite different. While some would see the last two as failures, they could in fact represent adaption to actual local needs [49]. On the other hand, if COP continues, is it a clear sign of its institutionalization and sustainability? The article on Kenya notes that, despite the existence of two state-led COP models, a broad gap remains between communities and police. Although the vision and programming for the cultivation of a people-centered police exists, too many pre-existing issues (police abuse, low trust, etc.) remain unaddressed. As a result, these initiatives serve to maintain the status quo rather than challenge problematic societal power structures, and true community-police collaboration remains a concept rather than a reality (Gjelsvik, this issue) [30]. The article on Kosovo details that despite COP implementation over many years, youths lack faith in their police due to lack of proper funding, training, performance and consistency; efforts to make COP both successful and sustainable would require these important perceptions to be addressed first
(Coenders, this issue) [31]. Similarly, Matute's article on Guatemala in this issue [50] notes that, without continued funding for activities, police will be forced to continue to rely on reactive policing techniques to address high levels of violence. Finally, Hansen's article in this issue reiterates that it is crucial to incorporate local contacts and institutions where possible, to assist and relieve police from ongoing threats [6]. In Afghanistan, police-community consultative groups are one example of how concepts of COP have been sustained through the traditional concept of the shura [51], which have provided venues for youth to express their security concerns. These cases illustrate that institutionalization and sustainability of COP are not only a function of how well a program is designed-they are influenced by wider social relations and political processes often outside of the control of the policing system.

\section{COP and Technology}

In addition to contextual aspects of policing systems, there are major gaps in the literature regarding the use of technology for COP and its ability to facilitate cooperation between police and citizens in these difficult contexts. As information and communication technologies (ICT) are rapidly developing and spreading, their use by police is increasingly discussed, also in the case of police assistance missions abroad. Most of the focus has been in using ICT to improve police efficiency, surveillance and crime reporting. Much less focus has been on how to use ICT in COP to improve communications and build trust between the police and communities. In our project we have attempted to identify what possibilities and limitations exist for the use of ICT for COP. Given the difficult contexts of intervention and the increased sensitivity of data integrity issues associated with the use of technologies in such contexts, the use of ICT remains a challenge. A key question we have asked in our work is: How do we ensure that ICT for COP is not co-opted for increased surveillance and the creation of a police state?

In the first special issue, Maqsood et al. the South Asian paper considers the different types of technologies used in policing in the region, and suggests that there is a potential for expanding the range of ICTs to go beyond their use for efficiency and surveillance, to contribute to trustbuilding [52]. While this is a relatively new area for policing, the use of ICTs for development began in the 1950s. The field of ICT for Development (ICT4D) can therefore provide useful experience around the contribution of technology to social, economic and environmental development. Mobile technology, for example, has been used to facilitate service delivery when other types of traditional infrastructure are lacking [53]. In Guatemala, WhatsApp has become a commonly-used tool for police to communicate with community representatives and with each other, while other tools such as image sharing and portable electronic fingerprint identifiers have facilitated police responses to crimes and emergencies (Matute, this issue) [50]. ICT4D scholars have 
also developed frameworks for ethical aspects [54] and for identifying risks and challenges in the use of ICT for development that might inform discussions of ICT for COP [55]. The particular challenges faced by youth described in this issue demonstrate the need for police to better utilize ICT to develop trust. For example, in Kosovo, youth reporting a stolen iPad to police lost faith in police upon learning that the responding officers were not aware of a popular app used to track stolen mobile devices (Coenders, this issue) [31]. Although staying up-to-date with the ways that youth use ICT (social media in particular) can be a challenge for police, it may provide an opportunity improve communication and alleviate insecurities between police and a vulnerable cross-section of society.

The challenges for ICT for COP are similar for those for ICT4D, including access and availability of technology infrastructure, privacy and security issues and the design of effective and affordable feedback loops, ICT capacity building for public sector actors, the strategic use of already available technologies, the integration of global and local experiences, and monitoring and evaluation [56]. Particularly challenging for ICT in both development and COP is the use of bottom-up approaches such as participatory technology development [57]. In policing, technology development is typically top-down and controlled by the police, who may neither trust the population, nor enjoy their trust. There is also a tendency to believe that technical solutions alone can replace the need for face-to-face communication. Evidence from our research suggests that is not so, particularly in contexts with trust deficits. In the first special issue, we saw that before recent mistakes, the Nicaraguan model had been successful largely based on its human and not technological interface [58]. Technologies are likely only a small part of a trust-building process, the nature of which are dependent on the context. The way a government, and particularly the police, uses technology may in fact be an indicator of how they view their relationship with civil society. In Pakistan, improving the image of the police and their relationship with communities is promoted using ICT at both national and provincial levels, but at the same time, the government has intensified its control of social media content and the use of online surveillance technology [52,59]. The articles in the current issue explore in depth issues of building trust, particularly with vulnerable populations, which, in turn, should be in the forefront as police consider how they will use ICTs in the future.

\section{Government-Civil Society Relations}

While it may seem that COP is merely the performance of a series of consultations, dialogues, and joint activities using good communication skills, as a policing approach it touches on the very essence of how governments relate to their populations. In the case of Kenya (Gjelsvik, this issue) [30], a historical precedent of abuse by police dating back to the colonial era, coupled with frequent violations of confidentiality for informants has discouraged cooperation between citizens and police, undermining COP efforts that aim to link the two groups. Instead, two separate COP efforts exist simultaneously, one of which operates largely outside of the police (Nyumba Kumi) while the other includes police (CPCs), resulting in political tension and confusion, rather than increased trust between the government and communities. In Guatemala, (Matute, this issue) [50], there remains little knowledge of COP among civil society, and where it is known it is often viewed with distrust based on the violent and repressive role of the police historically. Groups that are aware of COP expressed very different understandings of its meaning, with major variations between foreign donors, the government, civil society, and the police. Location has a significant effect on the degree of adaptation of COP: in areas with higher indigenous populations such as Totonicapan, police cooperate with representatives of indigenous municipalities that "have the final say". However, this is contrasted in more urban areas such as Villa Canales, where spaces set aside for police-community communication are not regularly utilized. Finally, in the case of Kosovo (Coenders, this issue) [31], youth reported that their efforts to report crime often went ignored by police, or that the police simply weren't capable of taking action on any information they were provided.

The papers in this and the previous special issue offer insight into how community-oriented policing is practiced and understood in each specific context. They also illustrate the emergence of several common themes that need to be addressed when attempting to understand COP in post-conflict contexts. These include the following: the significance of political, social and gendered power relations at international, national and local levels; continued tensions within the police/government and between the need for surveillance and control and the provision of services to communities, limited understanding of the role of civil society and local institutions in COP, lack of attention to the insecurities of vulnerable populations such as women, youth and minorities, limited awareness of the potentials and dangers of the use of ICTs in these contexts, and the challenges of trust-building in societies where trust both between the police/government and society, and within society itself after conflict are clearly in a deficit. In subsequent publication and research we will continue to address and further develop these insights. 


\section{References and Notes}

[1] This editorial is a revised version of the editorial from the special issue "Community-Oriented Policing after Conflict-Emerging Perspectives". Available from: http://www.librelloph.com/journalofhumansecurity/ issue/view/33.

[2] Bayley D, Perito R. The Police in War: Fighting Insurgency, Terrorism, and Violent Crime. vol. 3. Lynne Rienner; 2010.

[3] Report of the High-level Independent Panel on Peace Operations (HIPPO) on Uniting Our Strengths for Peace: Politics, Partnership and People. United Nations; 2015. Available from: https://www.globalr2p. org/wp-content/uploads/2020/01/2015-UNGA-HIPPO-Report.pdf.

[4] The research cases include Afghanistan, Pakistan, Kenya, Somalia/Somaliland, Uganda, Nicaragua, Guatemala, El Salvador, BosniaHerzegovina, Serbia and Kosovo.

[5] See www.communitypolicing.eu for more information on the project.

[6] Suhrke A. The Peace in Between. In: Suhrke A, Berdal M, editors. The Peace In Between. Routledge; 2013. pp. 15-38.

[7] Hansen S. Striving for the Impossible? Policing and Territoriality in the War on Terror. Journal of Human Security. accepted.

[8] Stepputat F. We in This Together? Security, Development and the 'Comprehensive Approach' Agenda. In: McNeish J, Sander LJ, editors. Security and Development. Berghahn; 2013. pp. 19-35.

[9] Elhawary S, Foresti M, Pantuliano S. Development, Security and Transitions in Fragile States. Overseas Development Institute; 2010. Available from: https://www.odi.org/sites/odi.org.uk/files/odiassets/publications-opinion-files/5852.pdf.

[10] Stewart F. Development and Security. Conflict, Security \& Development. 2004;4(3):261-288. doi:10.1080/1467880042000319863.

[11] Nyborg I. When Local Meets Global—Negotiating Rural Livelihoods in the Face of Multiple Security and Development Discourses and Approaches in Afghanistan. In: Kjosavik D, Vedeld P, editors. The Political Economy of Environment and Development in a Globalised World-Exploring the Frontiers. Trondheim: Tapir Academic Press; 2011. pp. 373-393.

[12] Supporting Security and Justice. Development Assistance Committee, Organisation for Economic Co-operation and Development; 2007.

[13] Joint Communication to the European Parliament and the Council: Elements for an EU-wide Strategic Framework to Support Security Sector Reform. European Parliament; 2014. Available from: https: //eur-lex.europa.eu/legal-content/EN/TXT/?uri=JOIN:2016:31:FIN.

[14] Security Council Resolution 2151. European Parliament; 2016.

[15] Osland K. UN Policing: The Security-Trust Challenge. In: de Coning C, Peter M, editors. United Nations Peace Operations in a Changing Global Order. Palgrave Macmillan; 2019. pp. 191-209.

[16] Nyborg I, Ganapathy J, Nimruzi A. From Guns to Roses: Understanding Community-Oriented Policing in Afghanistan. Journal of Human Security. 2019;15(2):54-69. doi:10.12924/johs2019.15020054.

[17] The original list of the seven major areas of human security, for example, was economic security, food security, health security, environmental security, personal physical security, security of community life, and political security (UN 1994).

[18] Gasper D. Human Security: From Definitions to Investigating a Discourse. In: Martin M, Owen T, editors. Handbook of Human Security. Routledge; 2013. pp. 48-62.

[19] McCormack T. Power and Agency in the Human Security Framework. Cambridge Review of International Affairs. 2008;21(1):113-128. doi:10.1080/09557570701828618.

[20] Haq M. Reflections on Human Development. Oxford University Press; 1999.

[21] Human Security Now. Commission on Human Security. United Nations; 2003. Available from: https://reliefweb.int/sites/reliefweb. int/files/resources/91BAEEDBA50C6907C1256D19006A9353-chssecurity-may03.pdf.

[22] O’Brien K, Barnett J. Global Environmental Change and Human Security. Annual Review of Environment and Resources. 2013;38(1):373391. doi:10.1146/annurev-environ-032112-100655.

[23] Divon S. Police Reform and Power in Post Conflict Societies A Conceptual Map for Analysis. European Journal of Policing Studies. 2016;4(3):269-298. Available from: http://hdl.handle.net/11250/ 2490053.
[24] Brogden M. "Horses for Courses" and "Thin Blue Lines": Community Policing in Transitional Society. Police Quarterly. 2005;8(1):64-98. doi:10.1177/1098611104267328.

[25] Duffield M. The Development-Security Nexus in Historical Perspective: Governing the World of Peoples. In: Sorensen J, editor. Challenging the Aid Paradigm: Western Currents and Asian Alternatives (Rethinking International Development Series). Palgrave Macmillan; 2010. pp. 1-257.

[26] Paris R. Saving Liberal Peacebuilding. Review of International Studies. 2010;36:337-365. doi:10.1017/S0260210510000057.

[27] Richmond OP. The problem of peace: understanding the 'liberal peace'. Conflict, Security \& Development. 2006;6(3):291-314 doi:10.1080/14678800600933480.

[28] Coyne A, Nyborg I. Pushing on a String? An Argument for Civil Society-driven Community Policing as Alternative to Ministry-centric Approach in Conflict-affected Areas. Journal of Human Security. accepted.

[29] Nyborg I. Emerging Perspectives on Post-Conflict PoliceCommunity Relations. Journal of Human Security. 2019;15(2) doi:10.12924/johs2019.15020001.

[30] Gjelsvik I. Police Reform and Community Policing in Kenya-The Bumpy Road from Policy to Practice. Journal of Human Security. accepted.

[31] Coenders F. There is Nothing Here: Growing up in Postconflict Kosovo. ICT4COP Policy Brief. 2019;(6). Available from: https://ict4copmagazine.files.wordpress.com/2020/02/6.-thereis-nothing-here-policy-brief-1.pdf.

[32] Ganapathy J, Nimruzi A, Ullah S. Fragile Futures: Youth as a Threat or Partner with Police in Security and Peacebuilding in Afghanistan and Pakistan. Journal of Human Security. under review.

[33] Bayley D. Democratizing the Police Abroad: What to Do and How to Do It. Issues in International Crime; 2001. Available from: https://www.ncjrs.gov/pdffiles1/nij/188742.pdf.

[34] Bloching S. Policing in Conflict: An Overview of EUPOL Afghanistan. European Science Foundation; 2011. Briefing 7.

[35] Marenin O. Restoring Policing Systems in Conflict Torn Nations: Process, Problems, Prospects. Geneva Centre for the Democratic Control of Armed Forces; 2005. 7. Occasional Paper.

[36] Dölling D, Feltes T. Community Policing: Comparative Aspects of Community Oriented Police Work. Holzkirchen; 1993.

[37] Jenkins S. Securing Communities: Summaries of Key Literature on Community Policing. Overseas Development Institute. 2013;Available from: https://www.odi.org/sites/odi.org.uk/files/odiassets/publications-opinion-files/8657.pdf.

[38] OSCE. Good Practices in Building Police-Public Partnerships. Organization for Security and Co-operation in Europe; 2008.

[39] OSCE. Guidebook on Democratic Policing. Organization for Security and Co-operation in Europe; 2008.

[40] Wisler D, Onwudiwe I. Community Policing: International Patterns and Comparative Perspectives. Boca Raton: CRC Press; 2009.

[41] Kyed H. Community Policing in Post-war Mozambique. Policing \& Society. 2009;19:354-371. doi:10.1080/10439460903375190.

[42] Brogden M, Nijhar P. Community Policing: National and International Models and Approaches. Cullompton: Willan Publishing; 2005.

[43] Denney L, Jenkins S. Securing Communities: The What and the How of Community Policing. Overseas Development Institute; 2013. Background Paper. Available from: http://www.odi.org/sites/odi.org. uk/files/odi-assets/publicationsopinion-files/8491.pdf.

[44] O'Neill W. Police Reform in Post-Conflict Societies: What We Know and What We Still Need to Know. The Security Development Nexus Program. International Peace Academy; 2005. Available from: https: //www.ipinst.org/wp-content/uploads/publications/polreferpt.pdf.

[45] Fridman O. Perspectives on Conflict. Structured and Unstructured Daily Encounters in Kosovo. Available from: http://www.transconflict.com/10/wp-content/uploads/2010/12/ StructuredUnstructuredDailyEncountersKosovo_Fridman.pdf.

[46] GCTF. Good Practices on Community Engagement and CommunityOriented Policing as Tools to Counter Violent Extremism. Global Counterterrorism Forum; 2009. Available from: https://www.thegctf org/documents/10162/159885/13Aug09_EN_Good+Practices+on+ Community+Engagement+and+Community-Oriented+Policing.pdf.

[47] Pino N, Ellison G. Globalization, Police Reform, and De- 
velopment: Doing it the Western Way? doi:10.2139/ssrn.2262711.

[48] Nyborg I, Ganapathy J. Introducing the Issues: Human Security, Development and the Civil Police in Afghanistan. Workshop Report for 'The Norwegian Police Engagement in Afghanistan: Perspectives on Security and Development for Local Women and Men'. Refleks; $2012 . \quad$ Available from: https://www.nmbu.no/sites/default/files/pdfattachments/ between_security_and_development_seminar_report_dec_2012.pdf.

[49] Wassel T. Institutionalising Community Policing in Timor-Leste: Police Development in Asia's Youngest Country. Overseas Development Institute; 2014. Available from: https://www.odi.org/sites/odi.org.uk/ files/odi-assets/publications-opinion-files/8841.pdf.

[50] Matute A. Struggling to Shake off the Conflict: An Assessment of the Experience of Community-Based Policing in Guatemala. Journal of Human Security. under review.

[51] Traditional groups of respected individuals in Afghanistan called together for discussion, debate, and conflict resolution.

[52] Maqsood T, Madani S, Bahadar N, Ullah S, Nyborg I. Role of ICT in Community-Oriented Policing in South Asia: Challenges and Opportunities. Journal of Human Security. 2019;15:21-40. doi:10.12924/johs2019.15020021.

[53] GSMA. Scaling Mobile for Development. GSMA Intelligence; 2013. Available from: https://www.gsmaintelligence.com/research/?file= 130828-scaling-mobile.pdf\&download.

[54] Dearden A. See no Evil? Ethics in an Interventionist ICTD. ACM International Conference Proceeding Series. 2012;19(2):1-17. doi:10.1145/2160673.2160680.

[55] Kemppainen J, Tedre M, Parviainen P, Sutinen E. Risk Identification Tool for ICT in International Development Co-operation Projects. The Electronic Journal on Information Systems in Developing Countries. 2012;55:1-26. doi:10.1002/j.1681-4835.2012.tb00391.x.

[56] Building Participatory Democracy through ICT. Stockholm University; 2013. Background Paper for Stockholm Internet Forum. Available from: http://www.spidercenter.org/polopoly_fs/1.150397.1381162681! /menu/standard/file/SIF_Background_paper_Spider_May_2013.pdf.

[57] Banks K. Reflections on a Decade of Mobiles in Development. Stability: International Journal of Security \& Development. 2013;2(3):1-5. doi:10.5334/sta.cm.

[58] McNeish JA, Martinez S, Frühling H, Ehrlich F. Community-Based Policing in Nicaragua: Do the Claims of Communitarian, Proactive and Preventative Hold True? Journal of Human Security. 2019;pp. 7-20. doi:10.12924/johs2019.15020007.

[59] Bahadar N, Ullah S, Nyborg I, Maqsood T. Community-Oriented Policing: Political, Institutional and Technical Reforms in Khyber Pakhtunkhwa (KP) Police. Journal of Human Security. 2019;15:4153. doi:10.12924/johs2019.15020041. 